\title{
Assessment of the roles of mitogen-activated protein kinase and phosphatidyl inositol 3-kinase/protein kinase B pathways in the basic fibroblast growth factor regulation of Sertoli cell function
}

\author{
M F Riera, S B Meroni, E H Pellizzari and S B Cigorraga \\ Centro de Investigaciones Endocrinológicas (CEDIE), Hospital de Niños ‘Ricardo Gutiérrez', Gallo 1330, (1425) Buenos Aires, Argentina
}

(Requests for offprints should be addressed to S B Cigorraga; Email: scigorraga @ cedie.org.ar)

\begin{abstract}
Basic fibroblast growth factor (bFGF) belongs to the large set of intratesticular regulators that provide the fine tuning of cellular processes implicated in the maintenance of spermatogenesis. The aim of the present study was to determine the participation of mitogen-activated protein kinase (MAPK) and phosphatidyl inositol 3-kinase/protein kinase B (PI3K/PKB) pathways in bFGF regulation of Sertoli cell function. Twenty-day-old rat Sertoli cell cultures were used. Stimulation of the cultures with bFGF showed a time-dependent increment in phosphorylated MAPK and PKB levels that reached maximal values in 5-min incubations. MAPK kinase inhibitors U0126 (U) and PD98059 (PD) and a PI3K inhibitor wortmannin (W) were able to block the stimulatory effects of bFGF on phosphorylated MAPK and PKB levels respectively. The participation of MAPK- and PI3K/PKB-signaling pathways in the regulation by bFGF of two well-known Sertoli cell-differentiated functions, lactate and transferrin production, was next explored. As for lactate production, PD and W did not modify the ability of bFGF to stimulate lactate production. However, a combination of PD and $\mathrm{W}$ partially impaired the increase in lactate production elicited by bFGF. The participation of MAPK- and PI3K/PKB-signaling pathways in the regulation by bFGF of glucose uptake and lactate dehydrogenase (LDH) activity was also analysed. In this respect, it was observed that W markedly decreased basal and bFGF-stimulated glucose uptake and that $U$ and PD did not modify it. On the other hand, $U$ and PD decreased the stimulation of LDH activity by bFGF whereas W did not modify it. As for transferrin production, while both MAPK kinase inhibitors partially decreased the ability of bFGF to stimulate transferrin secretion, the PI3K inhibitor did not modify it. In summary, the results demonstrated that bFGF stimulates MAPK- and PI3K/PKB-dependent pathways in rat Sertoli cells. Moreover, these results showed that while bFGF utilizes the MAPK pathway to regulate transferrin production and LDH activity, it uses the PI3K/PKB pathway to regulate glucose transport into the cell.
\end{abstract}

Journal of Molecular Endocrinology (2003) 31, 279-289

\section{Introduction}

A growing body of evidence suggests that basic fibroblast growth factor (bFGF) belongs to the large set of intratesticular regulators that provide the fine tuning of cellular processes implicated in the maintenance of spermatogenesis. bFGF exerts its effects by binding to receptors which belong to the tyrosine kinase family. Following ligand binding and dimerization, the receptors become capable of phosphorylating specific tyrosine residues on their own cytoplasmic tails and on each other's
(Lemmon \& Schlessinger 1994). Phosphorylated tyrosine residues, in turn, recruit other signaling molecules to the activated receptors and propagate the signal through several possible transduction pathways (Pawson 1995). Recently, Ong et al. (2001) have shown that, with the participation of different docking proteins, bFGF elicits bifurcating signals to activate the mitogen-activated protein kinase (MAPK) and phosphatidyl inositol 3-kinase/ protein kinase $\mathrm{B}$ (PI3K/PKB) pathways simultaneously in several cell lines. However, the activation of these signaling cascades may vary in 
different cell types. For example, the PI3K/PKB pathway is not triggered by bFGF in smooth muscle cells although it is an essential pathway for the maintenance of the differentiated phenotype of these cells (Hayashi et al. 1999). This fact probably reflects differences in the internal machinery to which the specific receptors are coupled in the different cell types.

bFGF has been found to modulate various non-mitogenic biological processes in a wide range of tissues and organs, including the testis, where bFGF has been shown to be produced (Ueno et al. 1987). Germ cells are a potential source of this peptide although other cells in the testis also express it (Mullaney \& Skinner 1992, Han et al. 1993). bFGF receptors are constitutively expressed in Sertoli cell cultures (Le Magueresse-Battistoni et al. 1994) and it has been shown that bFGF modulates, among other responses, the number of follicle-stimulating hormone $(\mathrm{FSH})$ receptors (Jaillard et al. 1987), transferrin, estradiol and lactate secretion (Han et al. 1993, Schteingart et al. 1999), glucose uptake, lactate dehydrogenase $(\mathrm{LDH})$ activity and the levels of glucose transporter 1 and LDH A mRNA (Riera et al. 2002).

Thus far, the signal transduction pathways that may be activated by bFGF in Sertoli cells have not been analyzed. Furthermore, no studies are available at present on the possible relationship between activated signaling cascades and specific biological responses in rat Sertoli cells. Therefore, the aim of the present study was to determine (a) whether bFGF is able to stimulate MAPK- and PI3K/PKB-signaling pathways in Sertoli cells and (b) to what extent these signaling pathways participate in bFGF regulation of Sertoli cell function.

\section{Materials and methods}

\section{Materials}

Human recombinant bFGF and tissue culture media were purchased from GIBCO BRL (Life Technologies Ltd, Rockville, MD, USA). Wortmannin (W), U0126 (U) and PD98059 (PD) were purchased from Biomol (Plymouth Meeting, PA, USA). $\left[2,6-{ }^{3} \mathrm{H}\right]$-2-deoxy-D-glucose (2-DOG) was purchased from NEN (Boston, MA, USA). All other drugs and reagents were purchased from Sigma Chemical Co. (St Louis, MO, USA).

\section{Sertoli cell isolation and culture}

Sertoli cells from 20-day-old Sprague-Dawley rats were isolated as previously described (Meroni et al. 1999). Briefly, decapsulated testes were digested with $0 \cdot 1 \%$ collagenase and $0 \cdot 006 \%$ soybean trypsin inhibitor in Hanks' balanced salt solution for $5 \mathrm{~min}$ at room temperature. Seminiferous tubules were saved, cut and submitted to $1 \mathrm{M}$ glycine- $2 \mathrm{mM}$ EDTA (pH 7.4) treatment to remove peritubular cells. The washed tubular pellet was then digested again with collagenase for $10 \mathrm{~min}$ at room temperature to remove germinal cells. The Sertoli cell suspension, collected by sedimentation, was resuspended in culture medium which consisted of a 1:1 mixture of Ham's F12 and Dulbecco's modified Eagle's medium, supplemented with $20 \mathrm{mM}$ HEPES, $100 \mathrm{IU} / \mathrm{ml}$ penicillin, $2.5 \mu \mathrm{g} / \mathrm{ml}$ amphotericin $\mathrm{B}, 1.2 \mathrm{mg} / \mathrm{ml}$ sodium bicarbonate, $10 \mu \mathrm{g} / \mathrm{ml}$ transferrin, $5 \mu \mathrm{g} / \mathrm{ml}$ insulin, $5 \mu \mathrm{g} / \mathrm{ml}$ vitamin $\mathrm{E}$ and $4 \mathrm{ng} / \mathrm{ml}$ hydrocortisone. Sertoli cells were cultured in 6- or 24-multiwell plates $(5 \mu \mathrm{g}$ DNA $/ \mathrm{cm}^{2}$ ) at $34{ }^{\circ} \mathrm{C}$ in a mixture of $5 \% \mathrm{CO}_{2}: 95 \%$ air.

No myoid cell contamination was revealed in the cultures when an immunoperoxidase technique was applied to Sertoli cell cultures using a specific antiserum to smooth muscle $\alpha$ actin. Remaining cell contaminants were of germ cell origin and this contamination was below 5\% after $48 \mathrm{~h}$ in culture as examined by phase contrast microscopy.

\section{Culture conditions}

Sertoli cells were allowed to attach for $48 \mathrm{~h}$ in the presence of insulin and medium was replaced at this time with fresh medium without insulin. Stimulation with bFGF was performed on day 3 in the presence or absence of MAPK kinase and PI3K inhibitors (U, PD and $\mathrm{W}$ ) as indicated in the figure legends. In all cases the inhibitors were added $15 \mathrm{~min}$ prior to the addition of bFGF. The 72-h conditioned media obtained on day 6 was used to evaluate transferrin and lactate levels. Cells harvested on day 6 were used to determine LDH activity. For 2-DOG uptake studies, cells cultured for 4 days under basal conditions pretreated for $2 \mathrm{~h}$ with bFGF in the presence or absence of the above-mentioned inhibitors were used. 


\section{Cell extracts and Western blot analysis}

Cells harvested on day 6 and cultured on 6-well plates, pretreated as indicated in the figure legends, were used for Western blot analysis. Cells were washed once with phosphate-buffered saline (PBS) at room temperature. Then, $200 \mu \mathrm{l}$ PBS containing $20 \mu \mathrm{l}$ of a protease inhibitor cocktail from Sigma (P-8340) and $2 \mathrm{mM}$ phenylmethylsulfonyl fluoride were added to the cells. Cells were then placed on ice and disrupted by ultrasonic irradiation. A $200 \mu \mathrm{l}$ volume of $2 \times$ Laemmli buffer $(4 \%$ (w/v) SDS, $20 \%$ (v/v) glycerol, 10\% (v/v) 2-mercaptoethanol, $0.004 \%(\mathrm{w} / \mathrm{v})$ bromophenol blue and $0.125 \mathrm{M}$ Tris-HCl, pH 6.8) was added and thoroughly mixed (Laemmli 1970). Samples were immersed in a boiling water bath for $5 \mathrm{~min}$ and then immediately settled on ice. Proteins were resolved in 10\% SDS-PAGE (10\% acrylamide/bisacrylamide for the resolving gel and $4 \cdot 3 \%$ acrylamide/ bisacrylamide for the stacking gel) in a Mini Protean 3 Cell (Bio-Rad, Hercules, CA, USA). After SDS-PAGE, gels were equilibrated in transfer buffer for $10 \mathrm{~min}$ and electrotransferred at $100 \mathrm{~V}$ for $60 \mathrm{~min}$ onto polyvinylidene difluoride membranes (Hybond-P; Amersham Pharmacia Biotech, Amersham, Bucks, UK) using a mini trans-blot cell (Bio-Rad). Membranes were probed with commercial kits (phosphoplus Akt Ser 473 antibody kit and phosphoplus p44/42 MAP kinase (Thr202/ Tyr204) antibody kit; New England Biolabs Inc., Beverley, MA, USA) that allow specific recognition of both total (T-PKB and T-MAPK) and phosphorylated (P-PKB and P-MAPK) PKB and MAPK. The intensities of the autoradiographic bands were estimated by densitometric scanning using NIH Image (Scion Corporation, Frederick, MD, USA) software.

\section{Transferrin determination}

Rat transferrin was measured by radioimmunoassay (RIA) as described by Handelsman et al. (1989). A polyclonal antibody raised against rat transferrin in rabbits was used (Cappel Laboratories, Cochranville, PA, USA). The cross-reactivity of human transferrin in this assay is less than $0.003 \%$. This RIA has a sensitivity of $3 \mathrm{ng} /$ tube and intra- and interassay coefficients of variation are $7 \%$ and $16 \%$ respectively.

\section{Measurement of 2-DOG}

Glucose transport was studied using the uptake of the labeled non-metabolizable glucose analogue 2-DOG. Cells were washed three times with glucose-free PBS at room temperature. Sertoli cells were then incubated at $34^{\circ} \mathrm{C}$ in $0.5 \mathrm{ml}$ glucosefree PBS containing $\left[2,6-{ }^{3} \mathrm{H}\right]-2-\mathrm{DOG}(0 \cdot 5 \mu \mathrm{Ci} / \mathrm{ml})$ for $30 \mathrm{~min}$. Unspecific uptake was determined in incubations performed in the presence of a 10000 -fold higher concentration of unlabeled 2-DOG. At the end of the incubation period, dishes were placed on ice and washed extensively with ice-cold PBS until no radioactivity was present in the washings. Cells were then dissolved with $0.5 \mathrm{M}$ sodium hydroxide and $0.4 \%$ sodium deoxycholate and counted in a liquid scintillation spectrophotometer. Parallel cultures receiving identical treatments to those performed before the glucose uptake assay were destined for DNA determinations. Results are expressed on a per $\mu \mathrm{g}$ DNA basis.

\section{LDH activity measurement}

After incubation of Sertoli cells in the absence or presence of the different stimuli, culture medium was discarded and cells were disrupted by ultrasonic irradiation in $\mathrm{NaCl}(0.9 \%)$ and centrifuged $(15800 \mathrm{~g}, 10 \mathrm{~min})$. The supernatant was used to measure total $\mathrm{LDH}$ activity. Total $\mathrm{LDH}$ activity was determined by a routinely used spectrophotometric method (Randox Laboratories, Crumlin, UK).

\section{Lactate determination}

Lactate was measured by a standard method involving conversion of $\mathrm{NAD}^{+}$to $\mathrm{NADH}$ determined as the rate of increase of absorbance at $340 \mathrm{~nm}$. A commercial kit from Sigma-Aldrich (St Louis, MO, USA) was used.

\section{Cell viability test}

A cell viability test was performed in cells cultured on 96-well plates and treated for $72 \mathrm{~h}$ with $\mathrm{U}, \mathrm{PD}$, $\mathrm{W}$ or a combination of both PD and W. A commercial kit (CellTiter 96 Aqueous NonRadioactive Cell Proliferation Assay; Promega Corporation, Madison, WI, USA) was used. 
A
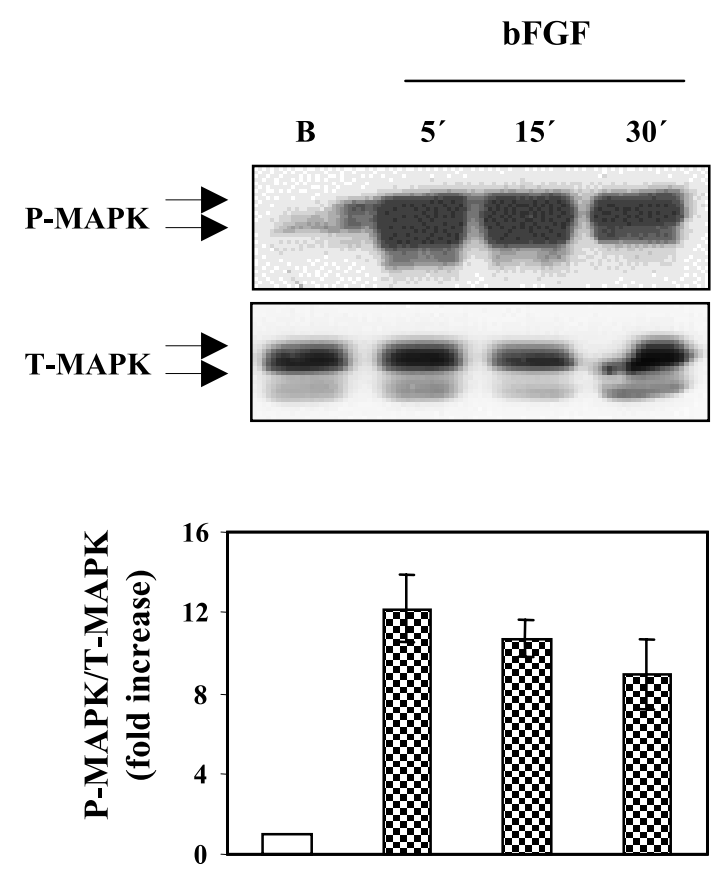

B
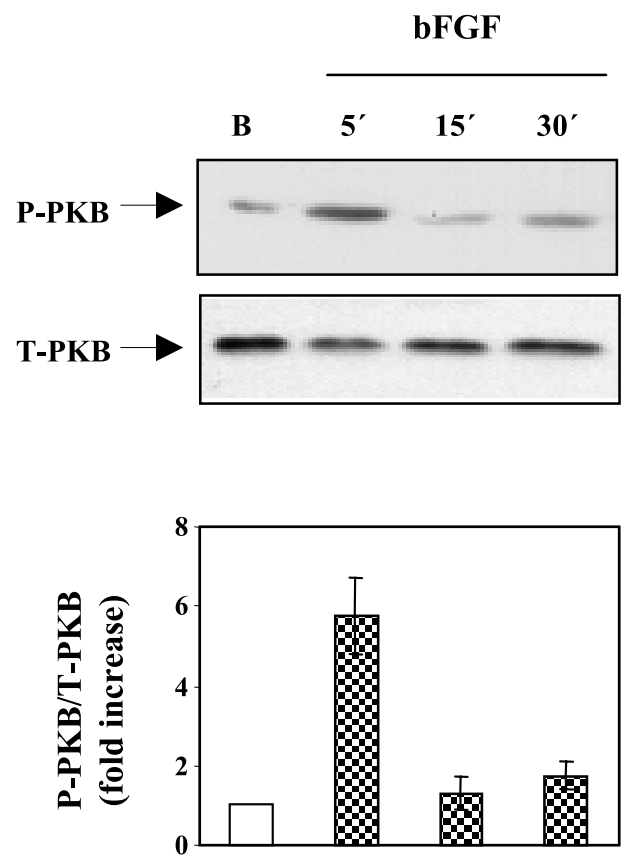

Figure 1 Effect of bFGF on P-MAPK and P-PKB levels in rat Sertoli cells. Sertoli cells were stimulated for variable periods of time $(5,15$ and $30 \mathrm{~min})$ with $30 \mathrm{ng} / \mathrm{ml} \mathrm{bFGF}$. Cell extracts were prepared at the designated intervals and utilized for Western blot analysis using antibodies specific for (A) T-MAPK or P-MAPK and (B) T-PKB or P-PKB. The upper panels show a representative experiment out of four. The lower panels show pooled data of four independent experiments indicating the fold increase in phosphorylation (ratio of P-MAPK to T-MAPK and of P-PKB to T-PKB in each sample) relative to basal. Results are expressed as means \pm S.D.

\section{Other assays}

DNA was determined by the method of Labarca \& Paigen (1980).

\section{Statistical analysis}

To analyze data from glucose uptake studies, transferrin and lactate production and $\mathrm{LDH}$ activity, one-way analysis of variance followed by the Tukey-Kramer test for multiple comparisons using the GB-STAT version 4·0 statistical program (Dynamic Microsystems Inc., Silver Spring, MD, USA) was performed. Probabilities $<0.05$ were considered statistically significant.

\section{Results}

\section{bFGF increases phosphorylated MAPK and PKB levels in rat Sertoli cells}

In order to evaluate a possible effect of bFGF on the levels of P-MAPK and P-PKB, Sertoli cell cultures were stimulated for variable periods of time $(5,15$ and $30 \mathrm{~min})$ with a dose of bFGF (30 $\mathrm{ng} / \mathrm{ml})$ that has been shown to elicit maximal biological responses (Riera et al. 2002). Stimulation of the cultures with bFGF produced a timedependent increment in P-MAPK and P-PKB levels that reached maximal values in 5-min incubations (Fig. 1A and B respectively). While P-PKB levels decreased in incubations longer than 5 min, P-MAPK levels remained elevated in 60- and 90-min incubations (five- and fourfold respectively, data not shown).

We next examined whether MAPK kinase inhibitors, $\mathrm{U}$ and $\mathrm{PD}$, and a PI3K inhibitor, W, were able to block the stimulatory effects of bFGF on P-MAPK and P-PKB levels. Cells were preincubated for $15 \mathrm{~min}$ with the inhibitors and then stimulated with bFGF for 5 min. Figure 2A shows that U (left panel) and PD (middle panel) dose-dependently decreased the ability of bFGF to increase the levels of P-MAPK and that W (right 
A
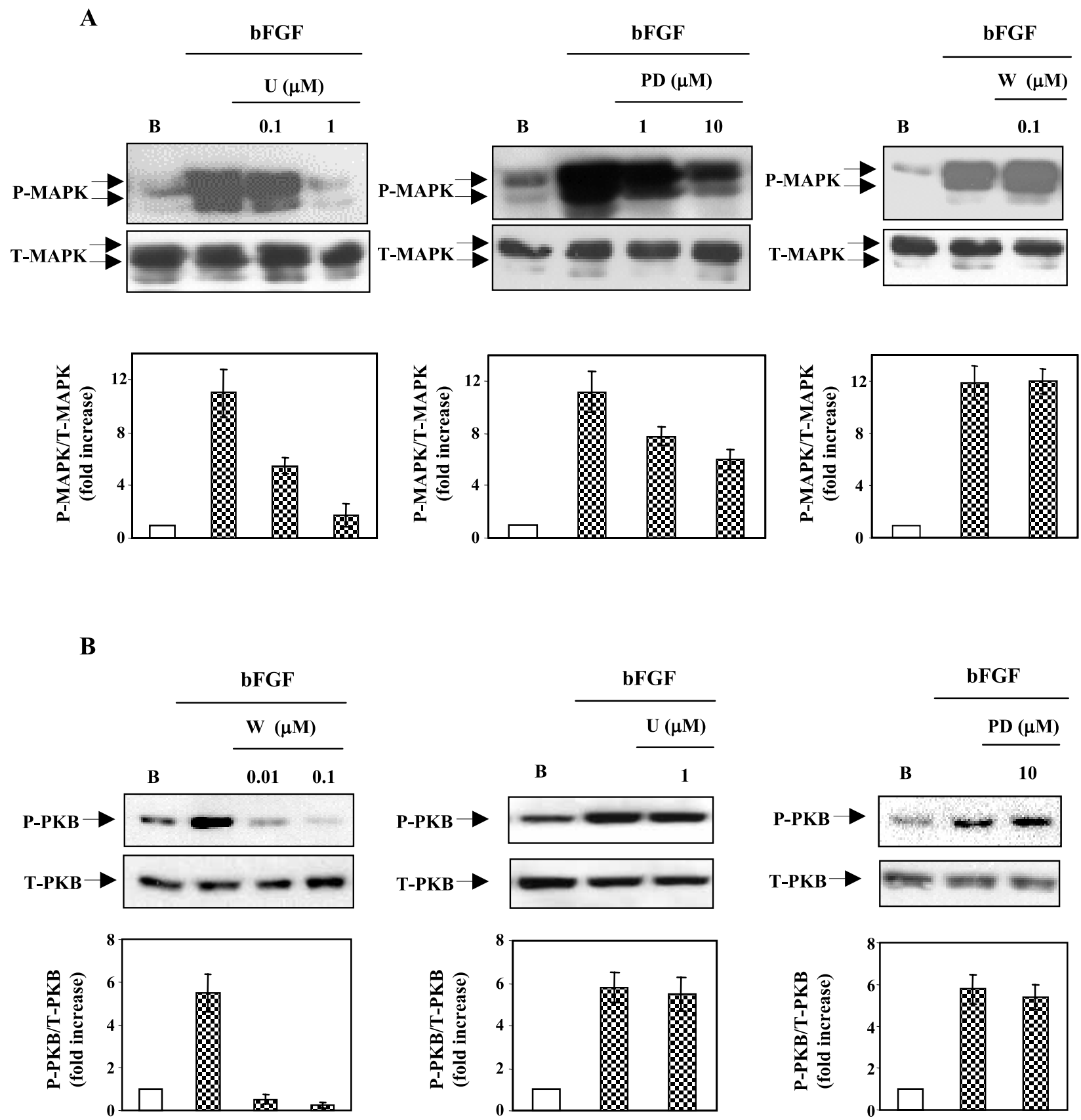

Figure 2 Effect of MAPK kinase and PI3K inhibitors on bFGF-stimulated levels of P-MAPK and P-PKB in rat Sertoli cells. (A) Sertoli cells preincubated or not for 15 min with $U(0.1$ and $1 \mu \mathrm{M})$, PD $(1$ and $10 \mu \mathrm{M})$ and $\mathrm{W}(0.1 \mu \mathrm{M})$ were stimulated for $5 \mathrm{~min}$ with $30 \mathrm{ng} / \mathrm{ml} \mathrm{bFGF}$. Cell extracts were prepared and utilized for Western blot analysis using antibodies specific for T- MAPK or P-MAPK. The upper panels show a representative experiment out of three. The lower panels show pooled data of three independent experiments indicating the fold increase in phosphorylation (ratio of P-MAPK to T-MAPK in each sample) relative to basal. Results are expressed as means \pm S.D. (B) Sertoli cells preincubated or not for 15 min with $W(0.01$ and $0.1 \mu \mathrm{M}), U(1 \mu \mathrm{M})$ and PD $(10 \mu \mathrm{M})$ were stimulated for 5 min with $30 \mathrm{ng} / \mathrm{ml}$ bFGF. Cell extracts were prepared and utilized for Western blot analysis using antibodies specific for T- PKB or P-PKB. The upper panels show a representative experiment out of three. The lower panels show pooled data of three independent experiments indicating the fold increase in phosphorylation (ratio of P-PKB to T-PKB in each sample) relative to basal. Results are expressed as means \pm S.D. 
Table 1 Effect of MAPK kinase and PI3K inhibitors on rat Sertoli cell viability. Sertoli cells were incubated for $72 \mathrm{~h}$ (day 3 to day 6$)$ without (control) or with $U(1 \mu \mathrm{M})$, PD $(10 \mu \mathrm{M}), \mathrm{W}(0.1 \mu \mathrm{M})$ or a combination of PD and $\mathrm{W}$ at the indicated doses. The cell viability assay was performed on day 6. Data are expressed as percentage of the control and are presented as means \pm S.D. of eight incubations in one representative experiment out of three

\begin{tabular}{ll} 
Control & $\begin{array}{l}\text { Cell viability } \\
\text { (\% of control) }\end{array}$ \\
\cline { 2 - 2 } U & 100 \\
PD & $100 \pm 7$ \\
W & $95 \pm 4$ \\
PD+W & $95 \pm 5$ \\
& $99 \pm 10$ \\
\hline
\end{tabular}

panel) did not modify it. On the other hand, Fig. $2 \mathrm{~B}$ shows that $\mathrm{W}$ (left panel) dose-dependently decreased the ability of bFGF to stimulate P-PKB levels but neither $\mathrm{U}$ nor PD (middle and right panels respectively) modified it. The inhibitors did not modify the low levels of basal P-MAPK and P-PKB (data not shown).

\section{MAPK- and PI3K/PKB-dependent pathways participate in bFGF regulation of Sertoli cell lactate production}

The next set of experiments was intended to analyze the relevance of bFGF-stimulated MAPKand PI3K/PKB-signaling pathways to Sertoli cell lactate production. The inhibitors $\mathrm{PD}, \mathrm{U}$ and $\mathrm{W}$ were added to the cultures $15 \mathrm{~min}$ prior to the initiation of a 72-h incubation period with bFGF. A cell viability test performed at the end of this $72-\mathrm{h}$ period showed that these inhibitors did not modify cell viability (Table 1).

Table 2 shows that PD, $\mathrm{W}$ and a combination of $\mathrm{PD}$ and $\mathrm{W}$ did not modify basal lactate production. It also shows that a combination of $\mathrm{PD}$ and W partially impaired the increase in lactate production elicited by bFGF.

We next analyzed the participation of MAPKand $\mathrm{PI} 3 \mathrm{~K} / \mathrm{PKB}$-signaling pathways in the regulation by bFGF of glucose uptake and $\mathrm{LDH}$ activity. Figure $3 \mathrm{~A}$ shows that $\mathrm{U}$ and $\mathrm{PD}$ were not able to modify the ability of bFGF to stimulate glucose uptake. On the other hand, Fig. 3B shows that $\mathrm{W}$ dose-dependently decreased the capacity of bFGF to increase glucose uptake. W also decreased
Table 2 Effect of MAPK kinase and PI3K inhibitors on basal and bFGF-stimulated lactate production in rat Sertoli cells. Sertoli cells were preincubated for $15 \mathrm{~min}$ without (control) or with PD $(10 \mu \mathrm{M}), \mathrm{W}(0.1 \mu \mathrm{M})$, or a combination of both inhibitors at the indicated doses in the absence (basal) or presence of $30 \mathrm{ng} / \mathrm{ml} \mathrm{bFGF} \mathrm{for}$ $72 \mathrm{~h}$. Lactate was determined in the 72-h conditioned media recovered on day 6 . Results represent means \pm S.D. of triplicate incubations in one representative experiment out of three

\begin{tabular}{|c|c|c|}
\hline & \multicolumn{2}{|c|}{$\begin{array}{l}\text { Lactate production } \\
(\mu \mathrm{g} / \mu \mathrm{g} \text { DNA })\end{array}$} \\
\hline & Basal & bFGF \\
\hline $\begin{array}{l}\text { Control } \\
\text { PD } \\
\text { W } \\
\text { PD+W }\end{array}$ & $\begin{array}{l}6 \cdot 1 \pm 0 \cdot 2^{\mathrm{a}} \\
5 \cdot 6 \pm 0 \cdot 4^{\mathrm{a}} \\
6 \cdot 3 \pm 0 \cdot 7^{\mathrm{a}} \\
6 \cdot 5 \pm 0 \cdot 3^{\mathrm{a}}\end{array}$ & $\begin{array}{l}14 \cdot 0 \pm 1 \cdot 2^{b} \\
12 \cdot 1 \pm 0 \cdot 9^{b} \\
13 \cdot 5 \pm 0 \cdot 8^{b} \\
10 \cdot 1 \pm 0 \cdot 3^{c}\end{array}$ \\
\hline
\end{tabular}

Different letters indicate $P<0.05$.

basal glucose uptake (data not shown). As for $\mathrm{LDH}$ activity, Fig. 4A shows that $\mathrm{U}$ and $\mathrm{PD}$ decreased the stimulation of $\mathrm{LDH}$ activity by bFGF whereas Fig. 4B shows that $\mathrm{W}$ did not modify it. None of the inhibitors modified basal $\mathrm{LDH}$ activity (data not shown).

\section{A MAPK-dependent pathway participates in bFGF regulation of transferrin secretion in Sertoli cells}

To analyze the relevance of bFGF-stimulated MAPK- and PI3K/PKB-signaling pathways to Sertoli cell transferrin secretion, the MAPK kinase inhibitors $\mathrm{U}$ and PD and the PI3K inhibitor $\mathrm{W}$ were added to the cultures $15 \mathrm{~min}$ prior to the initiation of a 72-h incubation period with bFGF. Figure 5A shows that $\mathrm{U}$ and PD partially inhibited the ability of bFGF to stimulate transferrin secretion. On the other hand, Fig. $5 \mathrm{~B}$ shows that $\mathrm{W}$ did not modify it. The inhibitors had no effect on basal levels of transferrin secretion (data not shown).

\section{Discussion}

Spermatogenesis is an intricate process highly dependent on Sertoli cell function which is under endocrine (FSH and testosterone) as well as autocrine and paracrine control which result from multiple and complex interactions between the 
A

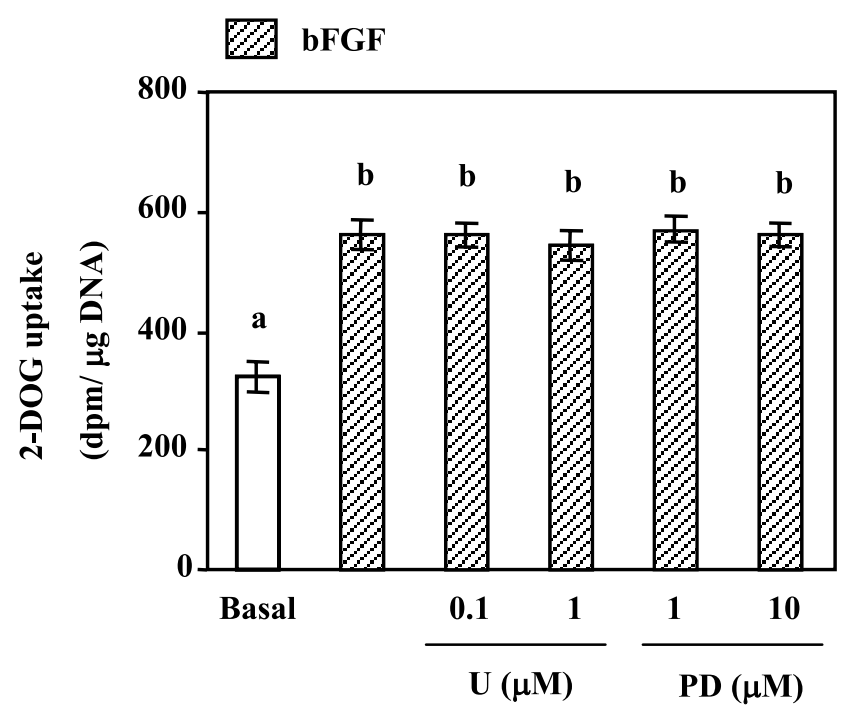

B

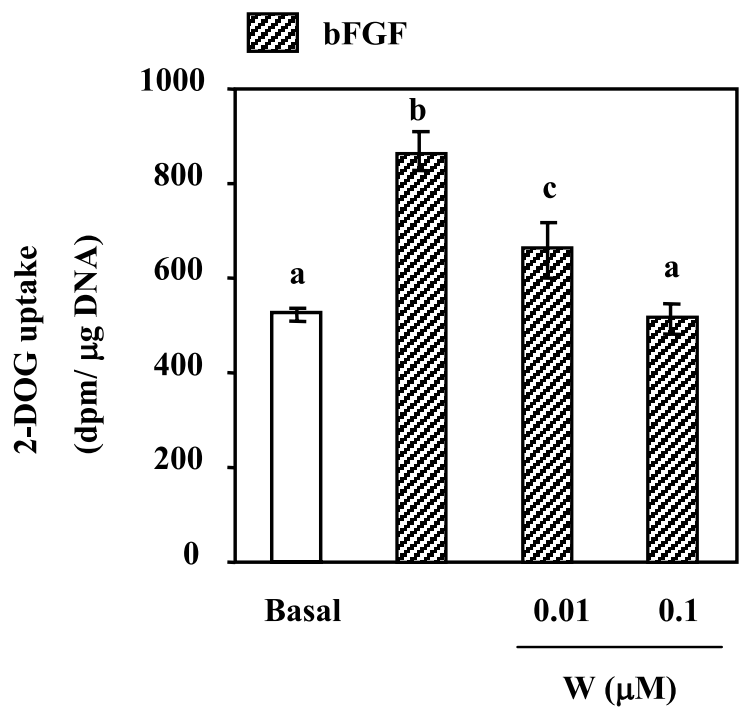

Figure 3 Effect of MAPK kinase and PI3K inhibitors on bFGF-stimulated glucose uptake in rat Sertoli cells. On day 5 , Sertoli cells preincubated or not for 15 min with $(A) U(0.1$ and $1 \mu M)$ and PD $(1$ and $10 \mu M)$ and $(B) W(0.01$ and $0.1 \mu \mathrm{M}$ ) were stimulated for $2 \mathrm{~h}$ with $30 \mathrm{ng} / \mathrm{ml} \mathrm{bFGF}$. Glucose uptake assay was performed after this incubation period. Results represent the means \pm S.D. of triplicate incubations in one representative experiment out of three. Different letters indicate statistically significant differences $(P<0.05)$.

A

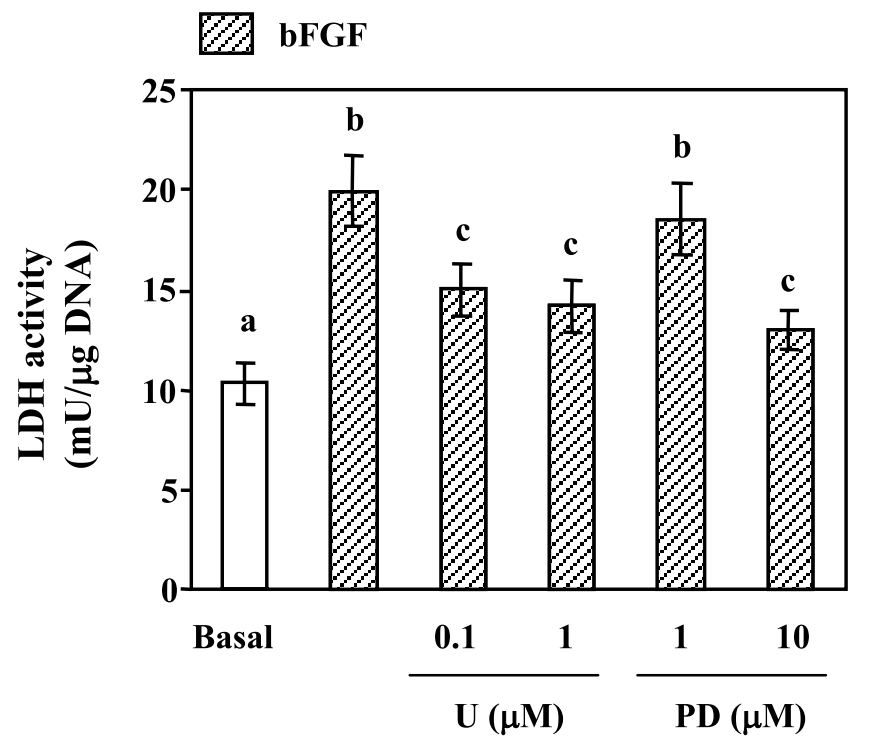

B

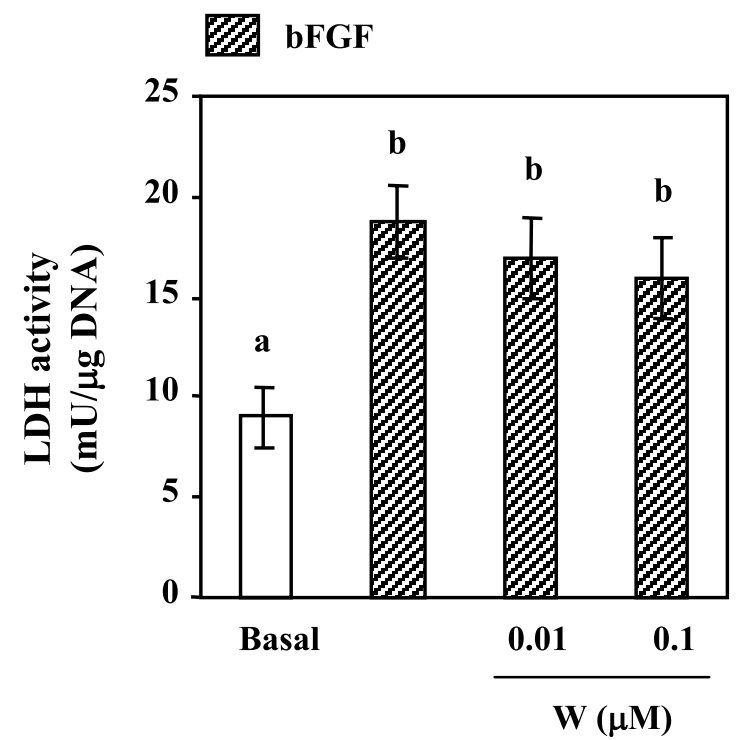

Figure 4 Effect of MAPK kinase and PI3K inhibitors on bFGF-stimulated LDH activity in rat Sertoli cells. On day 3 , Sertoli cells preincubated or not for 15 min with $(A) U(0.1$ and $1 \mu \mathrm{M})$ and $P D(1$ and $10 \mu M)$ and $(B)$ W $(0.01$ and $0.1 \mu \mathrm{M}$ ) were stimulated for $72 \mathrm{~h}$ with $30 \mathrm{ng} / \mathrm{ml} \mathrm{bFGF}$. LDH activity was determined on cells harvested on day 6 . Results represent the means \pm S.D. of triplicate incubations in one representative experiment out of three. Different letters indicate statistically significant differences $(P<0.05)$. 
A

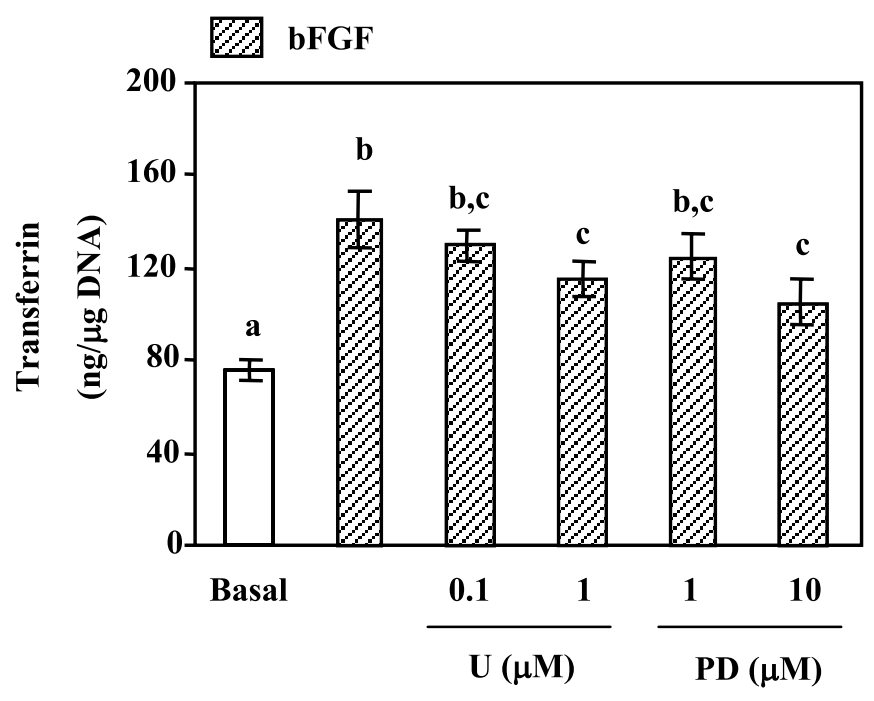

B

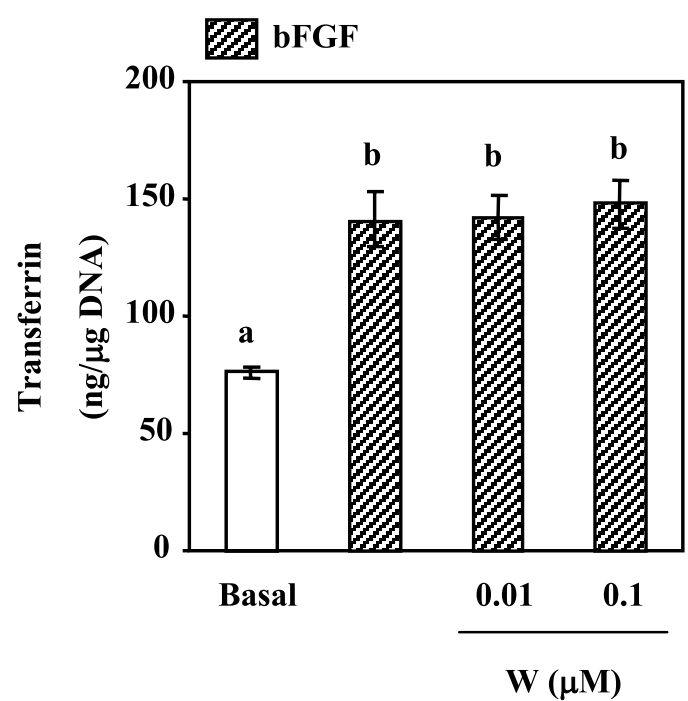

Figure 5 Effect of MAPK kinase and PI3K inhibitors on bFGF-stimulated transferrin secretion in rat Sertoli cells. On day 3 , Sertoli cells preincubated or not for 15 min with $(A) U(0.1$ and $1 \mu \mathrm{M})$ and PD $(1$ and $10 \mu \mathrm{M})$ and $(B) \mathrm{W}(0.01$ and $0.1 \mu \mathrm{M}$ ) were stimulated for $72 \mathrm{~h}$ with $30 \mathrm{ng} / \mathrm{ml} \mathrm{bFGF}$. Transferrin was determined in the $72-\mathrm{h}$ conditioned media recovered on day 6 . Results represent the means \pm S.D. of triplicate incubations in one representative experiment out of three. Different letters indicate statistically significant differences $(P<0.05)$.

different testicular cells (Parvinen 1982). In this context, receptors, site of production and biological responses elicited by growth factors have been analyzed in the different testicular cell types (reviewed in Gnessi et al. 1997). bFGF belongs to this complex family of peptides and, as mentioned in the Introduction, regulates several Sertoli cell biological functions. However, the signal transduction pathways that bFGF utilizes in Sertoli cells have not been studied. Moreover, no reports are at present available to allow a correlation between bFGF-activated signaling pathways and Sertoli cell biological responses.

The present work shows that bFGF induces a rapid and marked activation of MAPK- and PI3K/PKB-signaling pathways in rat Sertoli cells. But this activation lasts differently in either case: while P-MAPK levels were elevated for at least $90 \mathrm{~min}, \mathrm{P}-\mathrm{PKB}$ levels markedly decreased in incubations longer than $5 \mathrm{~min}$. As expected, inhibition of MAPK kinase with $\mathrm{U}$ and PD decreased P-MAPK levels but did not modify P-PKB levels and, conversely, inhibition of PI3K activity with $\mathrm{W}$ decreased P-PKB levels but did not modify P-MAPK levels. Thus, the use of the above-mentioned inhibitors in combination with
bFGF stimulation constituted a useful tool to analyze to what extent MAPK and PI3K/PKB pathways are involved in $\mathrm{bFGF}$ regulation of particular Sertoli cell functions.

Activation of the PI3K/PKB pathway has been previously shown to be associated with supporting differentiated functions of several cell types, including Sertoli cells (Meroni et al. 2002). On the other hand, the MAPK pathway was first recognized by its association with cell division and later on with a diverse array of cellular processes (Pearson et al. 2001). At 20 days of age in the rat, Sertoli cells have lost their ability to undergo mitosis. Therefore, it may be assumed that activation of the MAPK pathway by bFGF might also be related to the regulation of Sertoli cell-differentiated functions.

When analyzing the participation of MAPK- and $\mathrm{PI} 3 \mathrm{~K} / \mathrm{PKB}$-signaling pathways in the regulation by bFGF of two well-known Sertoli cell-differentiated functions - lactate and transferrin production several interesting observations were made. Stimulation of lactate production by bFGF was not altered when incubations with the growth factor were performed in the presence of either a MAPK kinase inhibitor or a PI3K inhibitor. Notwithstanding, 
when inhibitors of both signaling cascades were present simultaneously, a partial inhibition of lactate production in response to bFGF was observed. These results suggested that both pathways might be participating in the regulation of the final biological response.

Riera et al. (2002) showed that increments in glucose uptake and in LDH activity are part of the mechanisms utilized by bFGF to increase lactate production. Therefore, we next analyzed the possible participation of MAPK- and PI3K/PKBsignaling pathways on the regulation of these two metabolic steps that are important contributors to the ability of a cell to increase its lactate production. The results presented herein show that W markedly decreased bFGF-stimulated glucose uptake. As W also affected basal glucose uptake levels these results may, at first glance, be interpreted as a consequence of decreased basal cell metabolism. However, two lines of evidence argue against this conclusion. (a) W did not affect cell viability in 72-h incubations and (b) $\mathrm{W}$ did not affect basal transferrin secretion or $\mathrm{LDH}$ activity and these Sertoli cell functional parameters should have been affected if a decreased basal cell metabolism had occurred. Consequently, these results may be interpreted as follows: (a) the decreased basal glucose uptake induced by $\mathrm{W}$ is a result of decreased basal PI3K activity that has been shown to be essential for the maintenance of glucose uptake and (b) the decreased ability of bFGF to stimulate glucose uptake in the presence of $\mathrm{W}$ can be accounted for by the inability of the growth factor to activate the PI3K/PKB-signaling pathway under this condition. These hypotheses gain further support from previous reports describing the essential role played by the PI3K/PKB pathway on the regulation of basal and insulinstimulated glucose transport into different cell types (Okada et al. 1994, Lee et al. 1995, Czech \& Corvera 1999) and on basal and FSH-stimulated glucose uptake in rat Sertoli cells (Meroni et al. 2002). Altogether, observations in the abovementioned studies and the results presented herein suggest that activation of the PI3K/PKB-signaling pathway may constitute a universal mechanism that participates in the regulation of glucose transport into different cell types and by different extracellular signals. On the other hand, based on the observed absence of effect of the MAPK kinase inhibitors on basal and bFGF-stimulated glucose uptake, it may be postulated that activation of the MAPK pathway by bFGF does not participate in the regulation of glucose transport into Sertoli cells. As for $\mathrm{LDH}$ activity, stimulation by bFGF was impaired in the presence of MAPK kinase inhibitors but not in the presence of the PI3K inhibitor. These results seem to indicate that, differently from that observed for glucose transport, a MAPK-dependent pathway participates in the regulation of LDH activity by bFGF.

Concerning transferrin production, both MAPK kinase inhibitors utilized in this study, PD and U, partially inhibited the ability of bFGF to stimulate transferrin secretion. These results suggest that the MAPK-signaling pathway, in a similar way to that observed for LDH activity, plays a role in bFGF regulation of transferrin production. On the other hand, the PI3K inhibitor $\mathrm{W}$ did not modify bFGF-stimulated transferrin secretion and this result would indicate that the transient activation of the PI3K/PKB-signaling pathway evoked by this growth factor is not related to the production of the iron transport protein.

The mechanisms involved downstream of MAPK activation have not yet been analyzed. However, it has been shown that (a) bFGF increases transferrin and LDH A mRNA levels in rat Sertoli cells (Han et al. 1993, Riera et al. 2002), (b) transferrin and LDH A gene promoters contain CRE-like and CRE sequences respectively (Short et al. 1994, Chaudhary \& Skinner 1999) and (c) MAPK relays the signal downstream by activating various proteins in the cell, including gene regulatory proteins like Elk-1, c-myc and CREB (Alvarez et al. 1991, Marais et al. 1993, Ginty et al. 1994, Xing et al. 1996). Taking into account this information, it is tempting to speculate that increased levels of phosphorylated CREB in response to bFGF might be involved in the regulation of transferrin and $\mathrm{LDH} A$ gene transcription. Such a hypothesis does not rule out the fact that activation of other transcription factors may also contribute to regulate the transcription of these genes. In this context, it is worth mentioning that transactivation by c-myc of LDH A gene in rat fibroblasts has also been observed (Shim et al. 1997).

Recent studies have shown that FSH, the pituitary hormone responsible for maintenance of Sertoli cell-differentiated function, activates the $\mathrm{PI} 3 \mathrm{~K} / \mathrm{PKB}$ pathway. Moreover, it has also been 
demonstrated that inhibition of PI3K by W partially decreases the ability of FSH to regulate transferrin secretion, $\mathrm{LDH}$ activity and glucose uptake (Meroni et al. 2002). These results have led to the conclusion that the PI3K/PKB pathway participates in the regulation of the abovementioned biological responses. However, as mentioned before, even though bFGF stimulates a $\mathrm{PI} 3 \mathrm{~K} / \mathrm{PKB}$ pathway, this pathway is not apparently involved in bFGF regulation of transferrin production and $\mathrm{LDH}$ activity. These results suggest that within the same cell type several hormones may share a particular signal transduction pathway and yet the participation of this pathway in the regulation of cell function by each hormone may differ.

In summary, results presented herein demonstrate that bFGF stimulates MAPK- and PI3K/ PKB-dependent pathways in rat Sertoli cells. Moreover, these results show that while bFGF utilizes the MAPK pathway to regulate transferrin production and LDH activity, it uses the PI3K/ PKB pathway to regulate glucose transport into the cell. This study reveals the utilization of bifurcating signals elicited by $\mathrm{bFGF}$ to regulate distinct biological responses in rat Sertoli cells.

\section{Acknowledgements}

The technical help of Mercedes Astarloa is gratefully acknowledged. We also thank Celia Nieto for revising our English usage. The work was supported by grants from the Agencia Nacional de Promoción Científica y Tecnológica (PICT 00-05-08681) and CONICET (PIP 02866), Argentina. S B M and S B G are established investigators of CONICET.

\section{References}

Alvarez E, Northwood IC, Gonzalez FA, Latour DA, Seth A, Abate C, Curran T \& Davis RJ 1991 Pro-Leu-Ser/Thr-Pro is a consensus primary sequence for substrate protein phosphorylation. Characterization of the phosphorylation of c-myc and c-jun protein by an epidermal growth factor receptor threonine 669 protein kinase. Fournal of Biological Chemistry 266 15277-15285.

Chaudhary J \& Skinner MK 1999 E-box and cyclic adenosine monophosphate response elements are both required for folliclestimulating hormone-induced transferrin promoter activation in Sertoli cells. Endocrinology 140 1262-1271.
Czech MP \& Corvera S 1999 Signaling mechanisms that regulate glucose transport. Fournal of Biological Chemistry $\mathbf{2 7 4}$ $1865-1868$.

Ginty DD, Bonni A \& Greenberg ME 1994 Nerve growth factor activates a Ras-dependent protein kinase that stimulates c-fos transcription via phosphorylation of CREB. Cell $\mathbf{7 7}$ 713-725.

Gnessi L, Fabbri A \& Spera G 1997 Gonadal peptides as mediators of development and functional control of the testis: an integrated system with hormones and environment. Endocrine Reviewes $\mathbf{1 8}$ 541-609.

Han IS, Sylvester SR, Kim KH, Schelling ME, Venkateswaran S, Blanckaert VD, McGuinness MP \& Griswold MD 1993 Basic fibroblast growth factor is a testicular germ cell product which may regulate Sertoli cell function. Molecular Endocrinology 7 889-897.

Handelsman DJ, Spaliviero JA, Kidston E \& Robertson DM 1989 Highly polarized secretion of inhibin by Sertoli cells in vitro. Endocrinology 125 721-729.

Hayashi K, Takahashi M, Kimura K, Nishida W, Saga H \& Sobue K 1999 Changes in the balance of phosphoinositide 3-kinase/ protein kinase $\mathrm{B}(\mathrm{Akt})$ and mitogen-activated protein kinases (ERK/p38 MAPK) determine a phenotype of visceral and vascular smooth muscle cells. Fournal of Cell Biology 145 727-740.

Jaillard C, Chatelain PG \& Sáez JM 1987 In vitro regulation of pig Sertoli cell growth and function: effects of fibroblast growth factor and somatomedin-C. Biology of Reproduction 37 665-674.

Labarca C \& Paigen K 1980 A simple, rapid and sensitive DNA assay procedure. Analytical Biochemistry 102 344-352.

Laemmli UK 1970 Cleavage of structural proteins during the assembly of the head of bacteriophage T4. Nature 277 680-685.

Lee AD, Hansen PA \& Hollosky JO 1995 Wortmannin inhibits insulin-stimulated but not contraction-stimulated glucose transport activity in skeletal muscle. FEBS Letters 361 51-54.

Le Magueresse-Battistoni B, Wolff J, Morera AM \& Benahmed M 1994 Fibroblast growth factor receptor type 1 expression during rat testicular development and its regulation in cultured Sertoli cells. Endocrinology 135 2404-2411.

Lemmon MA \& Schlessinger J 1994 Regulation of signal transduction and signal diversity by receptor oligomerization. Trends in Biochemical Science 19 459-463.

Marais R, Wynne J \& Treisman R 1993 The SRF accessory protein Elk-2 contains a growth factor-regulated transcriptional activation domain. Cell 73 381-393.

Meroni SB, Cánepa DF, Pellizzari EH, Schteingart HF \& Cigorraga SB 1999 Effect of N-acetylsphingosine (c2) and ceramidase inhibitor (1S,2R)-D-erythro-2-(N-myristoylamino)-1-phenyl-1propanol on the regulation of Sertoli cell function. Fournal of Andrology 20 619-625.

Meroni SB, Riera MF, Pellizzari EH \& Cigorraga SB 2002 Regulation of rat Sertoli cell function by FSH: possible role of phosphatidylinositol 3-kinase/protein kinase B pathway. Fournal of Endocrinology 174 195-204.

Mullaney BP \& Skinner MK 1992 Basic fibroblast growth factor (bFGF) gene expression and protein production during pubertal development of seminiferous tubule: follicle-stimulating hormoneinduced Sertoli cell bFGF expression. Endocrinology 131 2928-2934.

Okada T, Kawano Y, Sakakibara T, Hazeki O \& Ui M 1994 Essential role of phosphatidylinositol 3-kinase in insulin-induced glucose transport and antilipolysis in rat adipocytes. Studies with a selective inhibitor wortmannin. Fournal of Biological Chemistry 269 3568-3573.

Ong SH, Hadari YR, Gotoh N, Guy GR, Schlessinger J \& Lax I 2001 Stimulation of phosphatidylinositol 3-kinase by fibroblast 
growth factor receptor is mediated by coordinated recruitment of multiple docking proteins. PNAS $986074-6079$.

Parvinen M 1982 Regulation of the seminiferous epithelium. Endocrine Reviews 3 404-417.

Pawson T 1995 Protein modules and signaling networks. Nature 373 573-580.

Pearson G, Robinson F, Gibson TB, Xu B, Karandikar M, Berman K \& Cobb MH 2001 Mitogen-activated protein (MAP) kinase pathways: regulation and physiological functions. Endocrine Reviews 22 153-183.

Riera MF, Meroni SB, Schteingart HF, Pellizzari EH \& Cigorraga SB 2002 Regulation of lactate production and glucose transport as well as of glucose transporter 1 and lactate dehydrogenase A mRNA levels by basic fibroblast growth factor in rat Sertoli cells. Journal of Endocrinology 173 335-343.

Schteingart HF, Meroni SB, Canepa DF, Pellizzari EH \& Cigorraga SB 1999 Effects of basic fibroblast growth factor and nerve growth factor on lactate production, $\gamma$-glutamyl transpeptidase and aromatase activities in cultured Sertoli cells. European Fournal of Endocrinology 141 539-545.

Shim H, Dolde C, Lewis BC, Wu CS, Dang G \& Jungmann RA 1997 c-Myc transactivation of LDH-A: implications for tumor metabolism and growth. PNAS 94 6658-6663.

Short ML, Huang D, Milkowski DM, Short S, Kunstman K, Soong CJ, Chung KC \& Jungmann RA 1994 Analysis of the rat lactate dehydrogenase A subunit gene promoter/regulatory region. Biochemical Foumal 304 391-398.

Ueno N, Baird A, Esch F, Ling N \& Guillemin R 1987 Isolation and partial characterization of bFGF from bovine testis. Molecular and Cellular Endocrinology 49 189-194.

Xing J, Ginty DD, \& Greenberg ME 1996 Coupling of the Ras-MAPK pathway to gene activation by RSK2, a growth factor-regulated CREB kinase. Science 273 959-963.

Received 15 May 2003

Accepted 23 June 2003 